\title{
MATA KULIAH PENDIDIKAN KEWARGANEGARAAN SEBAGAI UPAYA MEMUPUK RASA NASIONALISME MAHASISWA (Studi Kasus Pada Mahasiswa Universitas Buana Perjuangan Karawang) \\ ${ }^{1}$ Yogi Nugraha \\ ${ }^{1}$ Dosen Pendidikan Pancasila dan Kewarganegaraan \\ Fakultas Keguruan dan Ilmu Pendidikan \\ Universitas Buana Perjuangan Karawang \\ Email: yogi.nugraha@ubpkarawang.ac.id
}

\begin{abstract}
This study aims to describe the implementation of civic education courses in an effort to foster a sense of nationalism student at the Buana Perjuangan Karawang University. This study used a qualitative approach with the method used is the case study. Research conducted at the Buana Perjuangan Karawang University, with an estimated study time for start of the date October 28, 2017 until August 28, 2018. The target population in this study were students who follow courses of civic education, and sampling using techniques purposive sampling. The results obtained show that nationalism formed through civic education in college can be formed. It is based on a statement cited by respondents stated that the Civic Education is very important to learn in college, it's based on the erosion of a sense of nationalism began to be immediately addressed by studying Civics. Civic education is also learned to go back to the students will be taught by the teacher candidates Pancasila and Civic Education. Increased sense of nationalism in studying Civics is proof that Civic Education is so important to learn.
\end{abstract}

Keywords: Civic Education, Nationalism, Students.

\section{ABSTRAK}

Penelitian ini bertujuan untuk mendeskripsikan pelaksanaan mata kuliah pendidikan kewarganegaraan dalam upaya memupuk rasa nasionalisme mahasiswa di Universitas Buana Perjuangan Karawang. Penelitian ini menggunakan pendekatan kualitatif dengan metode yang digunakan yaitu metode studi kasus. Penelitian dilaksanakan pada Universitas Buana Perjuangan Karawang, dengan estimasi waktu penelitian selama mulai dari tanggal 28 Oktober 2017 sampai dengan tanggal 28 Agustus 2018. Populasi target dalam penelitian ini adalah mahasiswa yang mengikuti mata kuliah pendidikan kewarganegaraan, dan pengambilan sampel menggunakan teknik purposive sampling. Hasil penelitian yang diperoleh menunjukkan bahwa nasionalisme yang terbentuk melalui pembelajaran pendidikan kewarganegaraan di perguruan tinggi dapat terbentuk. Hal ini berdasarkan pernyataan yang diutarakan oleh para responden yang menyatakan bahwa Pendidikan Kewarganegaraan sangat penting untuk dipelajari di Perguruan Tinggi, hal ini didasarkan pada mulai lunturnya rasa nasionalisme haruslah segera diatasi dengan mempelajari Pendidikan Kewarganegaraan. Pendidikan Kewarganegaraan juga dipelajari untuk kembali dibelajarkan kepada peserta didik nantinya oleh para calon guru Pendidikan Pacasila dan Kewarganegaraan. Meningkatnya rasa nasionalisme dalam mempelajari Pendidikan Kewarganegaraan merupakan bukti bahwasanya Pendidikan Kewarganegaraan begitu penting untuk dipelajari.

Kata kunci: Pendidikan Kewarganegaraan, Nasionalisme, Mahasiswa. 


\section{PENDAHULUAN}

Sumpah pemuda 28 Oktober 1928 merupakan tonggak sejarah kebangkitan nasional. Titik kulminasinya adalah diproklamirkan kemerdekaan Indonesia pada 17 Agustus 1945 dan disahkannya Pancasila dan UUD 1945 pada 18 Agustus 1945. Peristiwa sejarah tersebut mengingatkan kepada kita bahwa rasa nasionalisme begitu penting dalam sendi-sendi kehidupan berbangsa dan bernegara. Jika kita melihat nilai-nilai luhur bangsa Indonesia maka seketika kita telah membuka lembaran sejarah bangsa Indonesia, kita bisa membuka mata kita dan menyadari kembali bahwa Indonesia memang diciptakan dari kemajemukan. Indonesia diciptakan dari berbagai macam perbedaan, baik perbedaan suku, perbedaan agama, perbedaan ras, perbedaan budaya, dan perbedaan warna kulit. Sebagai sebuah Negara yang ber-Bhinneka, kita meyakini dengan sungguhsungguh bahwa Indonesia memerlukan perekat rasa keIndonesiaan dalam berbagai macam perbedaan. Berbagai macam perbedaan yang ada jika tidak dirawat dengan rasa persatuan jelas akan menimbulkan berbagai macam konflik.

Kemerdekaan Indonesia yang menginjak usia 71 tahun seharusnya menjadi perhatian bagi kita semua selaku warga negara, sekaligus menjadi evaluasi bagi kita untuk mulai berpikir, berbuat dan memberikan sumbangsih untuk bangsa ini. Dewasa ini banyak ditemukan perilakuperilaku yang tidak mencerminkan kepribadian bangsa Indonesia. Praktek-praktek perilaku menyimpang yang terjadi di sebuah negara, merupakan pangkal dari kurangnya rasa nasionalisme dan rasa kecintaan terhadap Indonesia. Kurangnya rasa persatuan dan kesatuan serta kurangnya saling menghargai antar sesama bangsa Indonesia perlu menjadi perhatian bagi kita semua. Praktek-praktek saling mengagungkan dan menganggap diri sendiri atau golongannya paling benar mulai merebak di bumi Indonesia.

Persoalan tersebut membuat kita seakan lupa akan rasa nasionalisme kita yang semakin terkikis. Hal ini juga mulai menjangkiti mahasiswa yang seharusnya menjadi pelopor bangkitnya kembali rasa nasionalisme. Maka diperlukan sebuah usaha untuk kembali mengingatkan semua lapisan elemen bangsa untuk saling menghargai dan menghormati perbedaan yang ada di Indonesia. Semangat nasionalisme yang harus dijunjung tinggi, bukan malah semangat mengobarkan perbedaan yang ada yang pada ujungnya nanti membawa perpecahan bagi bangsa Indonesia. Mata kuliah Pendidikan Kewarganegaraan mencoba mengembalikan rasa nasionalisme yang kian terkikis dari dalam diri mahasiswa.

\section{METODE}

Penelitian ini menggunakan pendekatan kualitatif dengan metode studi kasus. Partisipan dalam penelitian ini adalah Mahasiswa Program Studi Pendidikan Pancasila dan Kewarganegaraan yang telah mempelajari matakuliah pendidikan kewarganegaraan.

Teknik pengambilan sampel dalam penelitian ini menggunakan purposive sampling. Purposive sampling adalah pengambilan sampel secara sengaja sesuai dengan persyaratan sampel yang diperlukan (Hidayati, 2014:52).

Sampel penelitian ini adalah 5 orang mahasiswa Program Studi 
Pendidikan Pancasila dan Kewarganegaraan Fakultas Keguruan dan Ilmu Pendidikan Universitas Buana Perjuangan Karawang.

Teknik pengumpulan data dalam penelitian ini dengan menggunakan observasi, wawancara, dokumentasi. Pengujian keabsahan data penulisan dilakukan dengan cara perpanjangan pengamatan dan triangulasi.

Triangulasi dilakukan dengan cara memanfaatkan metode, ini berarti peneliti mengadakan pengecekan derajat kepercayaan penemuan hasil penelitian beberapa teknik pengumpulan data dan pengecekan derajat kepercayaan beberapa sumber data dengan metode yang sama.

Teknik pengolahan dan analisis data menggunakan analisis proses siklus yang interaktif, menurut Miles dan Huberman (1992: 16-18) dengan tahapan sebagai berikut:

1. Pengumpulan data

a. Analisis sebelum di lapangan

Penelitian kualitatif telah melakukan analisis data sebelum peneliti memasuki lapangan. Analisis dilakukan terhadap data hasil studi pendahuluan atau data sekunder, yang akan digunakan untuk menemukan fokus penelitian.

b. Analisis selama di lapangan

Analisis data selama di lapangan dalam penelitian kualitatif dilakukan pada saat pengumpulan data berlangsung, dan setelah selesai pengumpulan data dalam periode tertentu. Secara sederhana dapat digambarkan analisa penelitian melalui beberapa langkah yaitu: peneliti membuat catatan-catatan hasil observasi baik yang intensif, partisipatif maupun gambaran yang kausal. Catatan ini segera dibuat deskripsi untuk menggambarkan masalah yang diteliti dari penampakan kasat mata baik dari sisi tindakan sosial yang dilakukan maupun dari sisi pengaruh situasi social dan lingkungan fisik yang terjadi. Gambaran ini memberikan panduan kepada peneliti kerangka analisa untuk melakukan rekonstruksi, membuat kategori dan konsep, melakukan interpretasi dan menjelaskan posisi serta lingkungan yang melengkapinya.

2. Penyajian data

yang $\begin{array}{cr}\text { Rakitan organisasi } & \text { informasi } \\ \text { memungkinkan adanya }\end{array}$ penarikan kesimpulan saat penelitian dilakukan. Dalam penyajian data diperoleh berbagai jenis metrik gambar, jaringan kerja, keterkaitan kegiatan atau tabel.

3. Reduksi Data

Setelah data dan informasi dari lapangan terkumpul, langkah kemudian adalah melakukan reduksi data yaitu menyajikan data secara jelas dan singkat. Penyajian data pertama kali dilakukan bagian demi bagian, kemudian dalam bentuk tabulasi. Selanjutnya disajikan dalam bentuk deskripsi dan interpretasi sesuai data yang diperoleh dari lapangan. Mereduksi data berarti merangkum, melihat hal-hal yang pokok, memfokuskan pada hal-hal yang penting, dicari tema dan polanya. Dengan demikian data yang telah direduksi akan memberikan gambaran yang jelas, dan mempermudah peneliti untuk melakukan pengumpulan data selanjutnya, dan mencari bila diperlukan. Reduksi data merupakan bagian dari analisis yang menajamkan, menggolongkan, mengarahkan, membuang yang tidak perlu, dan mengorganisasikan data dengan cara sedemikian rupa hingga kesimpulankesimpulan akhir dapat ditarik dan diverifikasi.

4. Penarikan Kesimpulan 
Langkah akhir dari proses analisis data adalah penarikan kesimpulan dan verifikasi, hal ini dimaksudkan untuk mencari makna dari data yang dikumpulkan. Kesimpulan ini dirumuskan dalam bentuk pernyataan singkat agar mudah dipahami dengan mengacu kepada tujuan penelitian yang telah ditetapkan. Proses analisis data berlangsung terus menerus selama kegiatan penelitian dilakukan. Untuk mencapai pada suatu kesimpulan, peneliti berusaha mengumpulkan data sebanyak-banyaknya dan menggali informasi yang lebih mendalam. Kesimpulan yang sudah dirumuskan masih harus terus diverifikasikan secara berulang dan bertahap hingga dapat dirumuskan kesimpulan akhir.

\section{HASIL PENELITIAN}

Setelah melakukan pengumpulan data di lapangan, peneliti menuangkan hasil wawancara dengan para informan dalam penjelasan yang dituangkan dalam deskripsi hasil penelitian. Data yang akan disajikan berikut merupakan hasil penelitian melalui wawancara mendalam dengan informan yang telah ditentukan oleh peneliti.

Dalam penelitian ini responden dari mahasiswa Program Studi Pendidikan Pancasila dan Kewarganegaraan yang berasal dari angkatan tahun 2015 dan tahun 2016. Mahasiswa tersebut diantaranya Feri Rizwan (angkatan 2016) yang selanjutnya disebut responden 1 , Muhamad Jawir Ripai (angkatan 2015) yang selanjutnya disebut responden 2, Kiki Nurmalasari (angkatan 2015) yang selanjutnya disebut responden 3, Muhtar Galuh Ardian (angkatan 2016) yang selanjutnya disebut responden 4 , dan Rano (angkatan 2016) yang selanjutnya disebut responden 5 .
Pertanyaan pertama yang diajukan oleh peneliti tentang Bagaimana perencanaan yang dilakukan oleh mahasiswa sebelum mempelajari mata kuliah pendidikan kewarganegaraan?

Menurut responden 1 persiapan yang dilakukan oleh responden 1 sebelum pelaksanaan matakuliah pendidikan kewarganegaraan adalah mempelajari secara mandiri terlebih dahulu terkait materi yang akan dipelajari di kelas. Kegiatan tersebut dapat melatih kesiapan diri sebagai seorang calon guru, maka mempersiapkan bahan ajar adalah suatu kewajiban yang harus dilaksanakan.

Materi perkuliahan jika dipelajari lebih awal oleh mahasiswa dapat menumbuhkan pemikiran kritis oleh mahasiswa. Oleh karena itu, kegiatan pembelajaran di kelas menjadi lebih berkembang dan menyenangkan. Seorang mahasiswa calon guru yang membiasakan mempersiapkan materi belajarnya akan mampu menjadi guru yang selalu siap mengajar dan mendidik peserta didiknya sesuai dengan indikatorindikator capaian belajarnya.

Menurut responden 2, persiapan yang dilakukan oleh responden 2 adalah Memahami warga belajar (the learner) dengan segala karakteristik dan kebutuhannya, memanfaatkan secara penuh segala sumber belajar untuk meningkatkan proses pembelajaran, melakukan kegiatan pengembangan, mengelola semua kegiatan mulai dari penyusunan rencana, pelaksanaan monitoring, revisi dan evaluasi, mengevaluasi hasil dan proses pembelajaran.

Menurut responden 3, persiapan yang dilakukan oleh responden 3 adalah melakukan persiapan dengan 
baik, menyusun dan mempelajari lebih awal materi yang akan di bahas.

Menurut responden 4, persiapan yang dilakukan responden 4 adalah sebelum mengikuti mata kuliah pendidikan kewarganegaraan secara tidak langsung otak merespon dan mengaitkan kewarganegaraan dengan pelajaran Pendidikan Pancasila dan Kewarganegaraan pada saat sekolah. Bisa jadi kata 'kewarganegaraan' di dalam memori otak tersimpan kuat karena setiap tahun dari sekolah dasar hingga sekolah menengah atas dipelajari pendidikan kewarganegaraan.

Menurut responden 5, persiapan yang dilakukan oleh responden 5 adalah membekali diri dengan sedikit membaca buku-buku tentang Pendidikan Kewarganegaraan.

Pada jawaban responden atas pertanyaan pertama mengenai perencanaan yang dilakukan oleh mahasiswa sebelum mempelajari mata kuliah pendidikan kewarganegaraan memperlihatkan bahwa mahasiswa melakukan persiapan yang beragam. Persiapan yang dilakukan berupa mempelajari sedikit tentang apa yang akan dipelajari melalui berbagai literature. Kemudian, persipaan lain yang dilaksanakan juga adalah memahami warga belajar. Hal ini dilakukan untuk melatih keterampilan calon guru dalam keahlian mengajarnya kelak di sekolah.

Pertanyaan Kedua yang
diajukan oleh peneliti adalah apa materi yang anda dapat selama mempelajari matakuliah Pendidikan kewarganegaraan?

Menurtut responden 2, selama mempelajari pendidikan kewarganegaraan pemahaman yang didapat adalah tentang Pengertian dan tujuan pendidikan kewarganegaraan, filsafat Pancasila, identitas nasional, demokrasi indonesia, negara dan konstitusi, rule of law dan HAM, geopolitik indonesia, dan geostrategi indonesia.

Menurut responden 2, selama mempelajari pendidikan kewarganegaraan pemahaman yang didapat adalah:

1. Pemahaman mengenai berbagai teori belajar dan prinsi-prinsip pembelajaran PKn

2. Pengetahuan dan keterampilan yang memadai pendekatan strategi, metode, dan teknik pembelajaran yang mendidik secara kreatif dalam mata pelajaran PKn.

3. Pemahaman yang baik mengenai tujuan pembelajaran PKn.

4. Pengetahuan dan keterampilan yang benar dalam pemilihan dan penataan materi PKn di sekolah.

5. Pemahaman yang baik mengenai media pembelajaran dan sumber belajar yang rekevan untuk PKn.

6. Pemahaman yang baik tentang prinsip-prinsip penilaian dan evaluasi proses dan hasil belajar bidang PKn.

7. Pengetahuan dan keterampilan dalam penelitian tindakan kelas bidang PKn.

Menurut responden 3, selama mempelajari pendidikan kewarganegaraan pemahaman yang didapat adalah Banyak, seperti Pendidikan Pancasila, Pendidikan Nilai dan moral, memahami normanorma yang beralaku, Undang-undang yang berlaku, Hukum yang mengatur dan lainnya

Menurut responden 4, selama mempelajari pendidikan kewarganegaraan pemahaman yang didapat adalah

1. Pancasila sebagai ideologi bangsa dan Negara

2. Pancasila sebagai suatu sistem filsafat 
3. Pancasila sebagai suatu filsafat negara Indonesia

4. hak dan asasi manusia

5. geopolitik indonesi

6. geostrategi Indonesia

Menurut responden 5, selama mempelajari pendidikan kewarganegaraan pemahaman yang didapat adalah Mulai dari Sejarah bangsa, Nasionalisme, Ham, Politik dan sistem pemerintahannya.

Pada jawaban responden atas pertanyaan kedua mengenai materi yang didapat selama mempelajari matakuliah

Pendidikan kewarganegaraan menunjukkan bahwa seluruh materi perkuliahan telah mampu dijabarkan secara lengkap oleh para responden. Ini artinya bahwa para responden setidaknya telah memahami mengenai materi-materi yang didapat selama pembelajaran.

Pertanyaan ketiga yang diajukan oleh peneliti adalah Apakah anda tertarik untuk mengikuti mata kuliah Pendidikan kewarganegaraan?

Menurut responden 1 tentu, mempelajari pendidikan kewarganegaraan sudah menjadi keharusan terutama bagi calon pendidik pendidikan kewarganegaraan selain meningkatkan pengetahuan sebagai warga negara, bisa juga menyampaikan ilmu pengetahuan kewarganegaraan kepada peserta didik.

Menurut responden 2, sangat tertarik karena Berdasarkan Pasal 3 Keputusan Dirjen Dikti No. 43/Dikti/2006 tentang Rambu-rambu Pelaksanaan Mata Kuliah Pengembangan Kepribadian di Perguruan Tinggi, Pendidikan Kewarganegaraan merupakan salah satu kelompok Mata Kuliah Pengembangan Kepribadian (MPK) yang dirancang untuk memberikan pengertian kepada mahasiswa tentang pengetahuan dan kemampuan dasar berkenaan dengan hubungan antar warga negara serta pendidikan pendahuluan bela negara sebagai bekal agar menjadi warga negara yang dapat diandalkan oleh bangsa dan negara.

Menurut responden 3 sangat tertarik, karna setiap materi yang di berikan apalagi mengenai arti pentingnya hidup dalam berkewarganegaraan selalu membuat saya antusias dalam mempelajarinya

Menurut responden 4 sangat tertarik, karena pendidikan kewarganegaraan mempunyai tujuan mewujudkan warga negara sadar bela negara berlandaskan pemahaman politik kebangsaan, kepekaan dalam mengembangkan jati diri dan moral bangsa dalam perikehidupan bangsa.

Menurut responden 5 sangat tertarik dengan Pendidikan Kewarganegaraan, karna perkuliahan ini mempelajari Negara ini sendiri.

Berdasarkan hasil jawaban yang diberikan oleh para responden satu sampai dengan lima, memperlihatkan bahwa adanya kesadaran yang tinggi bagi warganegara Indonesia untuk mempelajari Pendidikan Kewarganegaraan. Pendidikan Kewarganegaraan memberikan pengetahuan tentang Negara kepada warganegaranya.

Pertanyaan keempat yang diajukan oleh peneliti adalah Apakah Anda mengikuti perkuliahan Pendidikan kewarganegaraan dengan serius?

Menurut responden 1 mengikuti dengan serius, responden 1 mempunyai rencana agar suatu saat nanti bisa menyampaikan pendidika kewarganegaraan pada peserta didik. 
Menurut responden 2 mengikuti dengan serius, karena generasi penerus melalui pendidikan kewarganegaraan diharapkan akan mampu mengantisipasi hari depan yang senantiasa berubah dan selalu terkait dengan konteks dinamika budaya, bangsa, negara, dan hubungan internasional serta memiliki wawasan kesadaran bernegara untuk bela negara dan memiliki pola pikir, pola sikap dan perilaku yang cinta tanah air berdasarkan Pancasila. Semua itu diperlakukan demi tetap utuh dan tegaknya Negara Kesatuan Republik Indonesia.

Menurut responden 3 mengikuti dengan serius, karena dengan begitu kita dapat paham atas apa yang telah di pelajari pada perkuliahan Pendidikan Kewarganegaraan.

Menurut responden 4, serius atau tidaknya dalam mengikuti perkuliahan tergantung pada situasi dan kondisi pada saat itu.

Menurut responden 5 Serius sekali, tapi terkadang situasinya juga yang merubah keseriusan tersebut.

Berdasarkan jawaban responden atas pertanyaan keempat tersebut, memperlihatkan bahwa mayoritas responden mengikuti pembelajaran dengan serius karena manfaatnya akan sangat berguna bagi para responden khususunya sebagai calon seorang guru Pendidikan Pancasila dan Kewarganegaraan. Akan tetapi, ada juga yang mengatakan bahwa mempelajari materi Pendidikan Kewarganegaraan tergantung dengan situasi dan kondisi yang dipengaruhi oleh Dosen dan kondisi mahasiswa tersebut.

Pertanyaan kelima yang diajukan oleh peneliti adalah apakah arti nasionalisme yang Anda ketahui?

Menurut responden 1, Nasionalisme adalah satu paham yang menciptakan dan mempertahankan kedaulatan sebagai satu konsep identitas bersama untuk sekelompok manusia yang mempunyai tujuan atau cita-cita yang sama dalam mewujudkan kepentingan nasional, dan nasionalisme juga rasa ingin mempertahankan negaranya.

Menurut responden 2, Nasionalisme adalah satu paham yang menciptakan dan mempertahankan kedaulatan sebuah $\mathrm{n}$ egara dengan mewujudkan satu konsep identitas bersama untuk sekelompok manusia yang mempunyai tujuan atau cita-cita yang sama dalam mewujudkan kepentingan nasional, dan nasionalisme juga rasa ingin mempertahankan negaranya, baik dari internal maupun eksternal.

Menurut responden 3 Nasionalisme yaitu seseorang yang memiliki kecintaan terhadap negaraanya dan melakukan suatu kebaikkan untuk negaranya pula.

Menurut responden 4 nasionalisme berasal dari kata nation dan isme, nation berarti bangsa dan isme berarti paham, jdi nasionalisme adalah sekelompok manusia yang diam dalam suatu daerah tertentu dan memiliki hasrat kemauan untuk bersatu karena adanya persamaan nasib, cita-cita kepentingan dan tujuan.

Menurut responden 5, nasionalisme adalah rasa, rasa kecintaan terhadap negara saya yang tidak akan ternilai dengan apapun.

Berdasarkan jawaban responden pada pertanyaan kelima, memperlihatkan bahwa pengetahuan responden terhadap nasionalisme telah dipahami, ini adalah awal yang baik untuk dapat merealisasikan apa yang telah didapat selama mempelajari Pendidikan Kewarganegaraan. Nasionalisme memang sangat penting 
untuk diimplemenasikan ditengah kecenderungan merosotnya rasa nasionalisme generasi muda saat ini.

Pertanyaan keenam yang diajukan oleh peneliti adalah Menurut Anda, apakah penting rasa nasionalisme itu?

Menurut responden 1 penting, sebagai warga negara sudah menjadi sebuah keharusan mempertahankan negara sendiri.

Menurut responden 2 makna Nasionalisme secara politis merupakan kesadaran nasional yang mengandung cita-cita dan pendorong bagi suatu bangsa, baik untuk merebut kemerdekaan atau menghilangkan penjajahan maupun sebagai pendorong untuk membangun dirinya maupun lingkungan masy

Menurut responden 3 rasa nasionalisme sangat penting perlu adanya rasa nasionalisme didalam jiwa warga negara/masyarakat indonesia. Agar negara ini tetap utuh dan mampu mempertahankan kedaulatannya.

Menurut responden 4 nasionalisme sangatlah penting di dalam berbagai bidang kehidupan, Karena dengan nasionalisme yang tinggi maka persatuan dan kesatuan sebuah Negara akan semakin utuh dan kokoh.

Menurut responden 5 nasionalisne sangat penting, karna bila diibaratkan manusia, Nasionalisme itu jiwa dan bangsa adalah raganya.

Berdasarkan jawaban responden atas pertanyaan keenam tersebut menunjukkan bahwa kesadaran akan pentingnya rasa nasionalisme sangat erat kaitannya dalam mempertahankan keutuhan bangsa dan Negara.

Pertanyaan ketujuh yang diajukan oleh peneliti adalah apa manfaat yang Anda rasakan setelah mempelajari mata kuliah Pendidikan kewarganegaraan?

Menurut responden 1, selain mengetahui dan memahami pendidikan kewarganegaraan, bisa juga menyampaikan pada peserta didik maupun masyarakat yang kurang peduli pada negara.

Menurut responden 2

1. Berpikir secara kritis, rasional, dan kreatif dalam menghadapi berbagai masalah kewarganegaraan;

2. Berpartisipasi secara aktif dan bertanggung jawab, serta bertindak secara cerdas dalam kegiatan bermasyarakat, berbangsa, dan bernegara;

3. Berkembang secara positif dan demokratis untuk membentuk diri berdasarkan pada karakter-karakter masyarakat Indonesia agar dapat hidup secara berdampingan dengan sesama;

4. Berinteraksi dengan bangsa-bangsa lain dalam percaturan dunia secara langsung atau tidak langsung dengan memenfaatkan teknologi informasi dan komunikasi

Menurut responden 3, lebih mengerti arti hidup bekewarganegaraan yang baik, lebih mengenal Indonesia dengan nilai nilai moral dan kebudayaanya, mampu merubah mindset dalam menilai dan bersosial antar sesama, dan menuntut untuk mampu menjaga nilai dan moral sebagai mahasiswa PPKn

Menurut responden 4,

1. memiliki pandangan dan komitmen terhadap nilai-nilai demokrasi dan HAM

2. mampu berpartisipasi dalam upaya mencegah dan menghentikan berbagai tindak kekerasan dengan cara cerdas dan damai

3. memiliki kepedulian dan mampu berpartisipasi dalam upaya menyelesaikan konflik di 
masyarakat dengan dilandasi nilainilai moral, agama, dan nilai-nilai lainya.

4. mampu berpikir kritis dan objektif terhadap persoalan kenegaraan, HAM, dan demokrasi

5. mampu membumi aktifkan nilainilai dasar negara (pancasil) dalam bermasyarakat, berbangsa, dam bernegara

Menurut responden 5 Manfaat yang saya rasakan yaitu lebih mengerti tentang Negara saya.

Berdasarkan jawaban responden terhadap pertanyaan ketujuh menunjukkan bahwa banyak sekali manfaat yang dapat diambil dari mempelajari Pendidikan Kewarganegaraan. Keluasan pengetahuan yang terbangun selama mempelajari Pendidikan Kewarganegaraan memberikan gambaran bahwa mahasiswa telah mampu menangkap apa yang harus diketahui dan dipelajari selama belajar.

Pertanyaan kedelapan yang diajukan oleh peneliti adalah Apakah rasa nasionalisme anda meningkat setelah mempelajarai mata kuliah Pendidikan kewarganegaraan?

Menurut responden 1, meningkat yang tadinya kurang begitu peduli dengan negara, sekarang rasa ingin mempertahankan suatu dasar negara, falsafah negara, ideologi negara itu ada dalam diri.

Menurut responden 2,

1. Memiliki rasa cinta pada tanah air (patriotisme)

2. Bangga manjadi bagian dari bangsa dan masyarakat Indonesia

3. Menempatkan kepentingan bersama di atas kepentingan pribadi ataupun golongan

4. Mengakui dan menghargai sepenuhnya keanekaragaman yang ada pada bangsa Indonesia
5. Bersedia mempertahankan dan turut memajukan Negara serta menjaga nama baik bangsanya

6. Membangun rasa persaudaraan, solidaritas, perdamaian, dan anti kekerasan antar kelompok masyarakat dengan semangat persatuan dan kesatuan

7. Memiliki kesadaran bahwa kita merupakan bagian dari masyarakat dunia, sehingga bersedia untuk menciptakan perdamaian dunia dan menciptakan hubungan kerjasama yang saling menguntungkan

Menurut responden 3, meningkat karena didalam pendidikan kewarganegaraan banyak mempelajari hal-hal agar menjadi warga negara yang baik dan mencintai tanah air

Menurut responden 4 meningkat, karena matakuliah Pendidikan Kewarganegaraan mempelajari tentang bagaimana menjadi warga negara yang yang sadar akan bela negara, mengembangkan jati diri, dan moral bangsa dalam perikehidupan bangsa.

Menurut responden 5 meningkat, karena saya semakin bangga menjadi warga negara Indonesia.

Berdasarkan jawaban responden atas pertanyaan kelima menunjukkan bahwa terjadi peningkatan rasa nasionalisme para mahasiswa setelah mempelajari Pendidikan Kewarganegaraan.

Rasa nasionalisme sangat penting bagi warganegara. Menurut Ernest Renan (dalam https://kentibekti.wordpress.com/ppk $\mathrm{n}$ /pentingnya-rasa-nasionalisme/)

Nasionalisme adalah kehendak untuk bersatu dan bernegara. Maka dari itu, rasa nasionalisme akan muncul bila semua warganegara mempunyai rasa kehendak untuk bersatu. Usaha yang dapat dibangun dalam mempersatukan 
$\begin{array}{lr}\text { masyarakat adalah } & \begin{array}{r}\text { dengan } \\ \text { mempelajari Pendidikan } \\ \text { dimana }\end{array} \\ \text { Kewarganegaraan, } & \text { berbagai } \\ \text { didalamnya membahas } & \text { bnsur-unsur kebangsaan. }\end{array}$

DAFTAR RUJUKAN

Aliyah, (2015). Aktualisasi Pemikiran Nasionalisme Dalam

Pengembangan Indonesia Madani (Studi Fenomenologi Terhadap Perjuangan Moh. Natsir Dalam Pengembangan Nilai-nilai Kewarganegaraan).

Disertasi, Sekolah

Pascasarjana, Universitas Pendidikan Indonesia.

Asmara, D. (2013). Pengembangan Keterampilan Sosial Bagi Calon Guru (Studi Kasus Pada Program Praktik Kependidikan dan Khidmat Jamiyyah di Pesantren Muallimin Persatuan Islam 3 Pameungpeuk Kabupaten Bandung). Tesis, Sekolah Pascasarjana, Universitas Pendidikan Indonesia.

Bekti, (2013) Pentingnya Rasa Nasionalisme. Diakses dari https://kentibekti.wordpress.co $\mathrm{m} / \mathrm{ppkn} /$ pentingnya-rasanasionalisme/ [Diakses 20 Maret 2018].

Creswell, J. W. (1998). Qualitative inquiry and research design: choosing among five tradition. London: Sage Publication.
Keputusan Dirjen Dikti N0.43/DIKTI/KEP/2006.

Miles, M. B dan Huberman, A. (1992). Qualitative Data Analysis. Alih bahasa Tjejep Rohendi Rohidi. Analisis Data Kualitatif. Jakarta: Universitas Indonesia.

Moleong, Lexy J. (2007) Metodologi Penelitian Kualitatif, Bandung: Penerbit PT Remaja Rosdakarya Offset.

Senalice Mara (2013). Peran Pendidikan Kewarganegaraan dalam Membangun Nasionalisme Generasi Muda Untuk Mencegah Konflik di Papua (Studi Kasus Pada SMA Negeri 1 Abepura Jayapura). Tesis, Sekolah Pascasarjana, Universitas Pendidikan Indonesia.

Sukmadinata, S. N. (2009). Metode Penelitian Pendidikan. Bandung: Rosdakarya.

Sugiyono, (2011). Metode Penelitian Kuantitatif Kualitatif dan R\&D. Bandung: Alfabeta.

Suprayogo, I. (2001), Metodologi penelitian sosial. Rosdakarya, Bandung.

Undang-Undang Dasar Tahun 1945.

Undang-Undang Nomor 20 Tahun 2003 Tentang Sistem Pendidikan Nasional. 